\title{
FISCAL YEAR 1992 \\ ANNUAL OPERATING PLAN \\ FOR THE \\ GEOPRESSURED-GEOTHERMAL RESEARCH PROGRAM \\ (\$4.3 Million BUdget)
}

August 1991

Modification 1

Prepared By

Idaho National Engineering Laboratory
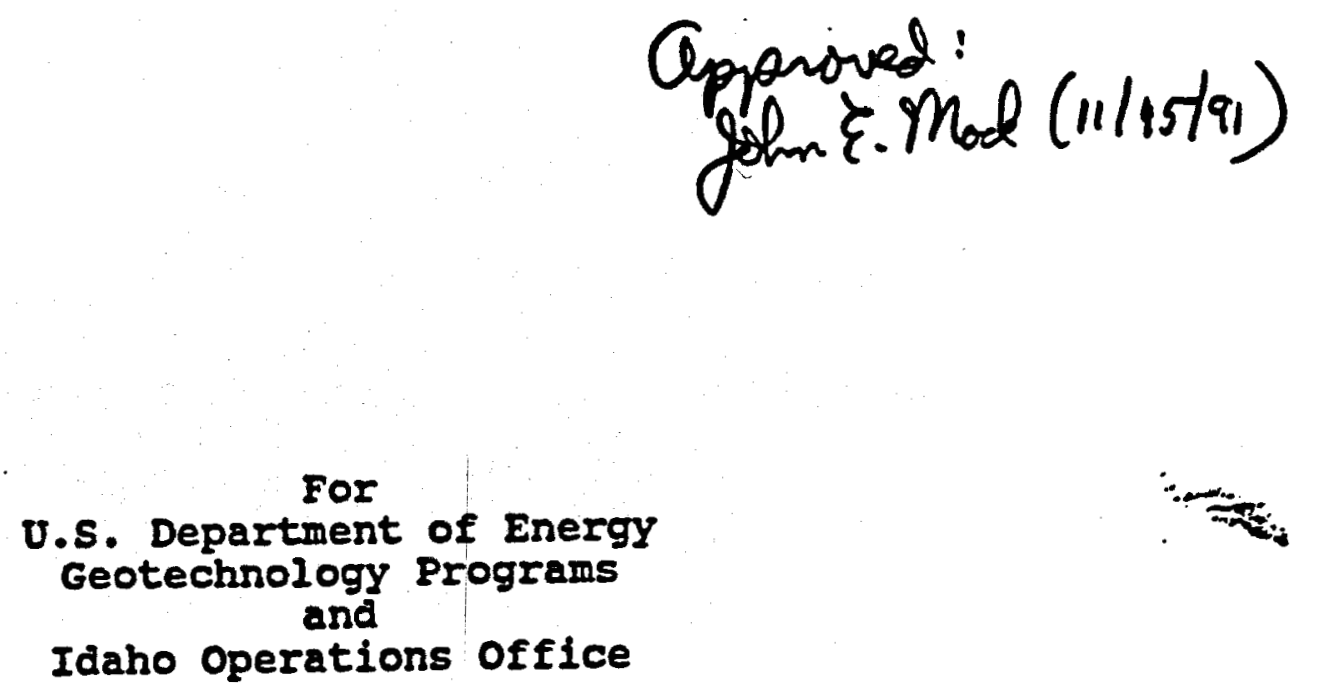


\section{DISCLAIMER}

This report was prepared as an account of work sponsored by an agency of the United States Government. Neither the United States Government nor any agency Thereof, nor any of their employees, makes any warranty, express or implied, or assumes any legal liability or responsibility for the accuracy, completeness, or usefulness of any information, apparatus, product, or process disclosed, or represents that its use would not infringe privately owned rights. Reference herein to any specific commercial product, process, or service by trade name, trademark, manufacturer, or otherwise does not necessarily constitute or imply its endorsement, recommendation, or favoring by the United States Government or any agency thereof. The views and opinions of authors expressed herein do not necessarily state or reflect those of the United States Government or any agency thereof. 


\section{DISCLAIMER}

Portions of this document may be illegible in electronic image products. Images are produced from the best available original document. 


\section{EXECUTIVE SUMMARY}

This plan describes the Geopressured-Geothermal Research Program. A a geopressured well in Texas (Pleasant Bayou) will undergo a pressure buildup test. A geopressured well in Louisiana (Gladys McCall) withe flow tested for a short period, logged, plugged and abandoned or turned over to industry edi $_{A}$ FY92. A second deep geopressured well in Louisiana, the Hul in Well, is being kept on stand by.

Related university

research in geology, numerical reservoir modeling, subsidence, microseismicity, and water quality will continue, with program data reviews initiated in appropriate areas. Increased emphasis on integrated reservoir engineering will be implemented. The well activities coupled with the related university research are designed to improve the ability to forecast reservoir productive capacity, to verify the reliability of the resource as a long-term energy resource, and to determine the environmental effects of long-term production. By these means, the Geopressured-Geothermal Research Program is developing a solid technology base that private industry can use to evaluate the geopressured-geothermal resource. The Industrial Consortium for utilization of the resource will be continued. Use projects in Louisiana and Texas will be evaluated. A geopressured reservoir review will be managed by

INEL. The DOE Field Ofsice, Idaho will make prepdrations to complete the Program. 
TABLE OF CONTENTS

Page

EXECUTIVE SUMMARY.$\ldots \ldots \ldots \ldots \ldots \ldots \ldots \ldots \ldots \ldots \ldots \ldots \ldots \ldots \ldots \ldots \ldots \ldots \ldots$

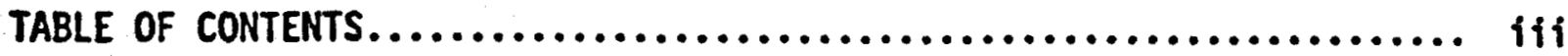

1.0 INTRODUCTION..................................... I

1.1 Objectives at the Category Level........................ I

1.2 Strategy Statement................................... l

1.3 Program Background Information.......................... 1

1.4 Scientific Approach................................... 2

1.5 Justification....................................... 2

1.6 Key Objectives at the Task Leve1........................ 2

1.7 Work Breakdown Structure............................... 4

2.0 PRIOR YEAR DATA.................................. 7

2.1 Well Operations Task................................. T

2.1.1 Task Description and Overview................... 7

$2.1 .2 \quad$ Funding............................................ 7

2.1.3 Manpower..................................... 7

2.1.4 Accomplishments............................., 7

2.2 Geoscience and Engineering Support Task.................. g

2.2.1 Task Description and Overview .................... 9

2.2.2 Funding......................................... 9

2.2.3 Manpower....................................... 9

2.2.4 Accomplishments.............................. 9

2.3 Energy Conversion Task............................. 16

2.3.1 Task Description and Overview................... 16

2.3.2 Funding......................................... 16

2.3.3 Manpower.......................................... 17

2.3.4 Accomplishments............................... 17 
2.4 INEL Management................................... 18

2.4.1 Task Description and Overview................... 18

2.4.2-3 Funding and Manpower........................... 18

2.4.4 Accomplishments............................ 18

3.0 FUNDING YEAR RESEARCH PLAN............................ 21

3.1 Project: Pleasant Bayou............................. 21

3.1.1 Issue..................................... 21

3.1.2 Project Description.............................. 21

3.1.3 Statement of Work............................. 21

3.1.4 Milestones..................................... 21

3.1.5 Deliverables................................. 21

3.1.6 Expected Accompl ishments........................ 22

3.1.7 Funding Requirement............................ 22

3.1.8 Manpower Requirement......................... 22

3.2 Project: Hul in Reservoir........................... 22

3.2 .1 Issue................................... 22

3.2.2 Project Description............................... 22

3.2.3 Statement of Work.............................. 22

$3.2 .4 \quad$ Milestones....................................... 22

3.2.5 Deliverabies................................. 23

3.2.6 Expected Accompl ishments....................... 23

3.2.7 Funding Requirement............................ 23

3.2.8 Manpower Requirement......................... 23

3.3 Project: Liquid Hydrocarbons........................ 23

3.3.1 Issue.................................... 23

3.3.2 Project Description............................ 23

3.3.3 Statement of Work................................ 23

3.3.4 Milestones...................................... 24

3.3.5 Deliverables.................................. 24

3.3.6 Expected Accompl ishments........................ 24

3.3.7 Funding Requirement........................... 24

3.3.8 Manpower Requirement............................ 24

3.4 Project: Reservoir Engineering...................... 24

3.4.1 Issue..................................... 24

3.4.2 Project Description............................... 24

3.4.3 Statement of Work............................... 25

3.4.4 Milestones....................................... 25

3.4.5 Deliverables................................... 25

3.4.6 Expected Accompl ishments........................ 25

3.4.7 Funding Requirement............................ 25

3.4.8 Manpower Requirement......................... 25 
3.5 Project: Vertical Seismic Profile..................... 25

3.5.1 Issue..................................... 25

3.5.2 Project Description........................... 26

3.5.3 Statement of Work............................. 26

3.5.4 Milestones................................... 26

3.5.5 Deliverables.................................. 26

3.5.6 Expected Accomplishments $. . \ldots \ldots \ldots \ldots \ldots \ldots \ldots \ldots, 26$

3.5.7 Funding Requirement.......................... 26

3.5.8 Manpower Requirement......................... 26

3.6 Project: Environmental Effect........................ 27

3.6.1 Issue.................................... 27

3.6.2 Project Description............................. 27

3.6.3 Statement of Work............................ 27

3.6.4 Milestones................................... 27

3.6.5 Deliverables................................ 28

3.6.6 Expected Accomplishments....................... 28

3.6.7 Funding Requirement............................ 28

3.6.8 Manpower Requirement................., ........ 28

3.7 Project: Strategies for Resource Utilization............. 28

3.7.1 : Issue...................................... 28

3.7.2 Project Description............................... 29

3.7.3 Statement of Work................................ 29

3.7.4 Milestones..................................... 29

3.7.5 Deliverables................................... 29

3.7.6 Expected Accomplishments...................... 29

3.7.7 Funding Requirement............................ 30

3.7.8 Manpower Requirement.......................... 30

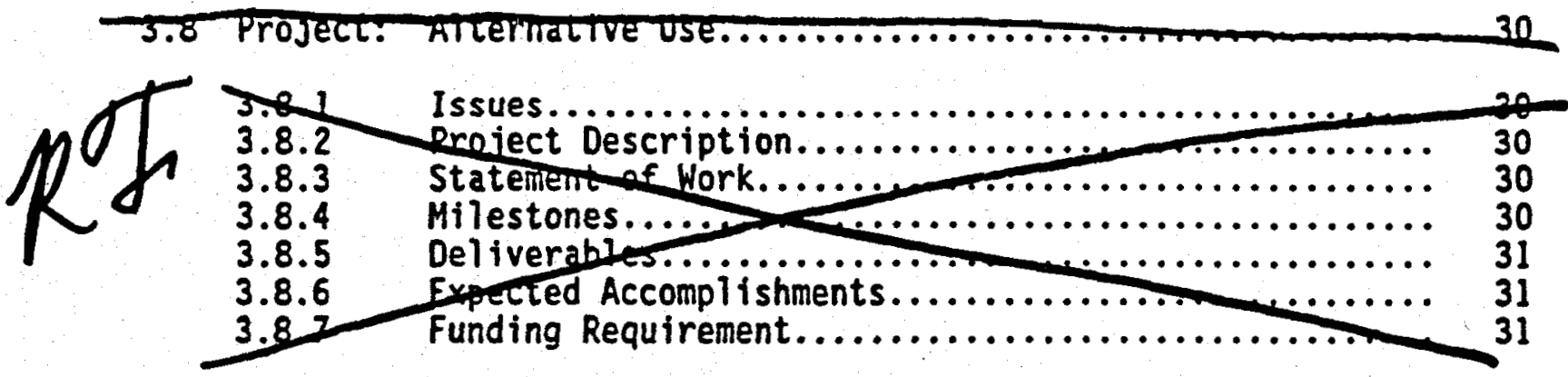

3.9 Project: INEL Management........................... 31

$3.9 .1 \cdots$ Issues.................................... 31

3.9.2 Project Description............................. 31

3.9.3 Statement of Work............................. 32

3.9.4 Milestones...................................... 33

3.9.5 Deliverables.................................... 34

3.9.6 Expected Accompl ishments....................... 34

3.9.7 Funding Requirement........................... 34 
3.9.8 Manpower Requirement........................ 34

4.0 MANAGEMENT PLAN.................................. 35

4.1 Overview of Management System........................ 35

4.2 Management Structure................................ 36

4.3 Management Resource Requirements..................... 38

4.4 Procurement Plan Summary............................ 38

4.5 Subcontracting $P 1$ an................................. 38

4.6 Schedules of Conferences and Technical Reviews.............. 38

4.7 Schedule of Planned Foreign Trave1.................... 39

5.0 OUTYEAR RESEARCH PLAN............................. 41

5.1 Goars/Objectives................................. 42

$5.2 \& 5.3$ Key Issues, Strategy, and Broad Task Descriptions....... 42

5.4 Outyear Funding Requirements......................... 45

5.5 Outyear Manpower Requirements......................... 45

APPENDIX

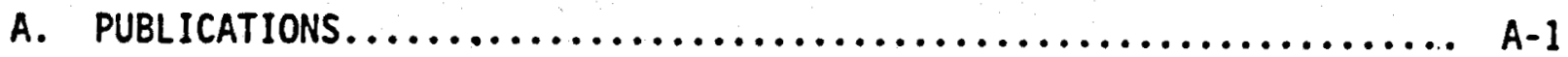

LIST OF TABLES

1. FY.92 Milestone Summary............................... 46

2. Overall Outyear Schedule and Control Milestones................ 47

3. Deliverables Summary $\ldots \ldots \ldots \ldots \ldots \ldots \ldots \ldots \ldots \ldots \ldots \ldots \ldots, 48$

4. Funding and Manpower by Project, Tasks, and Contractor for FY-92................................... 49 


\section{INTRODUCTION}

\subsection{Geopressured-Geothermal Objectives at the Category Level}

The category objective for Geopressured-Geothermal research is to improve the technology to the point where electricity could be produced commercially from a substantial number of geopressured resource sites via wells of opportunity. In some instances, industry may decide to sell only methane and thermal energy.

The present Geopressured-Geothermal Program is scheduled to be completed in FY-1993 with environmental monitoring extending into FY-1994. This will involve completing the testing and analysis at all three well sites and Plugging and Abandoning the wells. In addition, the present university research will be completed in FY-1993. The goal of this long standing program was to determine this vast energy resource. To that goal, three wells have been produced. Two of the wells have been produced in excess of three years. This data has been used by researchers to produce reservoir models and geopressured markers which can be used by future developers. In addition, a 1 MWe Hybrid Power System was designed, constructed, and tested under using the geopressured resource from the Pleasant Bayou reservoir.

\subsection{Strategy Statement}

The research program focuses on relatively narrow technical issues unique to geopressured resources, such as development of a capability to predict reservoir productive capacity based on preliminary flow tests.

\subsection{Program Background Information}

For a variety of reasons, thousands of oil and gas wells have been abandoned in the Gulf coast region. Many of those wells penetrated geopressured zones whose resource potential was undervalued or ignored. It is possible that in some instances the research may provide a basis for extension of the economic lives of some depleted or dry hydrocarbon wells, if those wells are recompleted as geopressured wells. 


\subsection{Scientific Approach}

The technical feasibility of extracting geopressured fluids has been demonstrated at a number of wells in Louisiana and Texas. Research to date has shown that the geopressured-geothermal resource is large and widespread; it is saturated or nearly saturated with methane; and it can be produced, used, and the residual brines disposed of with minimal operational and environmental problems. However, several technical and economic questions still remain. These are the focus of the present research program. The research and development is concentrated on:

- Conducting and analyzing flow tests of geopressured wells to ascertain reservoir drive parameters and operating conditions.

- Improving system control and energy conversion technology to optimize the rates and economics of energy extraction.

\subsection{Justification}

The U.S.G.S. estimates that sandstone aquifers onshore along the Gulf of Mexico Coast contain. 5700 quads of methane and $>73,000$ quads of thermal energy. Development of a solid technology base will enable private industry to evaluate the geopressured-geothermal resource as part of a balanced and mixed set of energy resource options for future energy market places.

\subsection{Key Task Objectives}

The category objective for geopressured-geothermal research is to improve the technology to the point where energy could be produced commercially from a substantial number of geopressured resource sites via wells of opportunity. The task objectives related to this category objective are covered in the following.

\subsubsection{Well Operations Task:}

The task objectives for Well Operations are: 
Prove the long term injectability of large volumes of spent fluid at multiple sites by 1992.

Develop surface fluid handling facilities (pumps, separators, valves, compressors, etc.) which can be safely operated from a remote monitoring location by 1993.

Develop material specifications, equipment specifications, and maintenance procedures which will allow over $95 \%$ annual availability with only annual shutdown for routine maintenance by 1993.

\subsubsection{Geoscience and Engineering Support Task}

The task objective for Geoscience and Engineering Support is:

Develop techniques to increase confidence in the ability to locate and evaluate geopressured-geothermal resources by 1992 such that at least 90 percent of wells recompleted for geopressured - geothermal development are subsequentiy shown to be economic.

Determine the drive mechanisms for the design of well reservoirs by 1992.

Determine source and flow mechanisms for the liquid hydrocarbons and methane being obtained from producing geopressured reservoirs by 1992.

Develop a test procedure which has sufficient accuracy to predict the capability of any geopressured reservoir to be produced for a period five times as long as the test period by 1993.

Determine if fluids can be disposed of in an environmentally acceptable manner by 1995 .

\subsubsection{Energy Converston Task}

The task objective for Energy Conversion is: 
Develop conversion technology with thermal efficiency at $20 \%$ greater than that from separate combustion and geothermal power cycles by 1992.

This task has been completed.

\subsubsection{Management Task}

The task objective for management is: Supply management and technical support to DOE-ID.

\subsection{Work Breakdown Structure}

Category: Geopressured-Geothermal

Task: Well Operation

- Project: Gladys McCall (Completed)

- Project: Pleasant Bayou

- Project: Hulin

Task: Geoscience and Engineering

- Project: Rock Mechanics (Completed)

- Project: Liquid Hydrocarbons
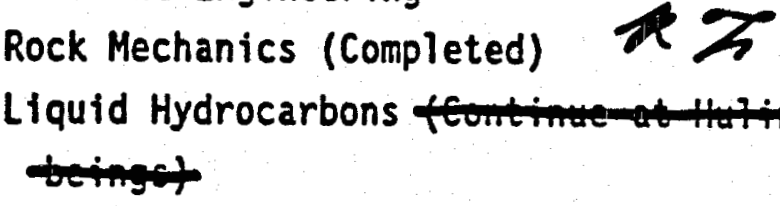

- Project: Reservoir Engineering

- Project: Logging (Completed)

- Project: Environmental Assessment

Task: Energy Conversion

- Project: Pleasant Bayou Hybrid Power System Testing (Completed)

Task: Management Support

- Project: General Administration

- Project: Alternative Use

- Project: Technology Transfer to Industry 
Develop conversion technology with thermal efficiency at $20 \%$ greater than that from separate combustion and geothermal power cycles by 1992.

This task has been completed.

\subsubsection{Management Task}

The task objective for management is: Supply management and technical support to DOE-ID.

\subsection{Work Breakdown Structure}

Category: Geopressured-Geothermal

Task: Well Operation

- Project: Gladys McCall (Completed)

- Project: Pleasant Bayou

- Project: Hul in

Task: Geoscience and Engineering

- Project: Rock Mechanics (Completed)

- Project: Liquid Hydrocarbons (Continue at Hul in if flow test beings)

- Project: Reservoir Engineering

- Project: Logging (Completed)

- Project: Environmental Assessment

Task: Energy Conversion

- Project: Pleasant Bayou Hybrid Power System Testing (Completed)

Task: Management Support

- Project: General Administration

- Project: Alternative Use

- Project: Technology Transfer to Industry 


\subsection{PRIOR YEAR DATA}

\subsection{Well Operations Task}

\subsubsection{Task Description and Overview:}

Three Gulf Coast geopressured-geothermal wells are being utilized to obtain information on reservoir performance under production conditions, surface handling systems, disposal well injection procedures, brine chemistry and scale inhibitor treatment, and automation. The well operations data are utilized by the universities in reservoir modeling, brine chemistry, and cryocondensate research. Complete pressure buildups and short-term flow test at Gladys MCCall design well, P \& A or turn over to industry. Commence high flow rate flow test $(30,000 \mathrm{bpd})$ at Pleasant Bayou design well with the future

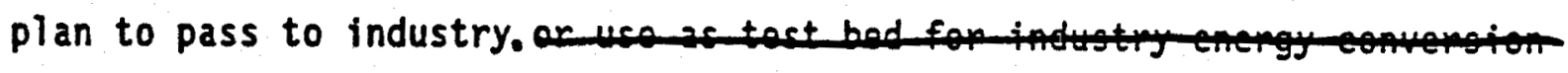
Ready Hul in well for flow test and place on standby.

\subsection{2-3 Funding and Manpower:}

$\begin{array}{ccc} & \begin{array}{c}\text { Funding } \\ (\$)\end{array} & \begin{array}{c}\text { Manpower } \\ (\mathrm{man} / \mathrm{yr})\end{array} \\ \text { FY-90 } & 3,393 \mathrm{~K} & 15.0 \\ \text { FY-91 } & 3,374 \mathrm{~K} & 15.0\end{array}$

\subsubsection{Accomplishments:}

For the Pleasant Bayou site in Texas: Significant FY-89, FY-90, and FY-91 accomplishments are:

- Pleasant Bayou surface facilities were constructed and flow testing begun. Tests 1-15 detailed in FY-88 AOP have been completed, and Test 23 is on-going.

- The Hybrid Power System was successfully tested for eight months. 
- Scaling and corrosion have been successfully monitored and controlled.

- Eaton has operated the Pleasant Bayou production well over $99 \%$ of the available time for the fiscal year. Rates have been up to over 25,000 BPD.

- The scale inhibitor squeezes done on the Pleasant Bayou production well have been very successful. As of April, the well has produced 16,000,000 barrels of brine, with no scale deposition in the well or in the surface production facilities.

- The corrosion treatment program at Pleasant Bayou has been very successful. There have been no corrosion failures in the fiscal year.

For the Gladys MCCall site in Louisiana. Significant accomplishments for FY-89, FY-90 and FY-91 are:

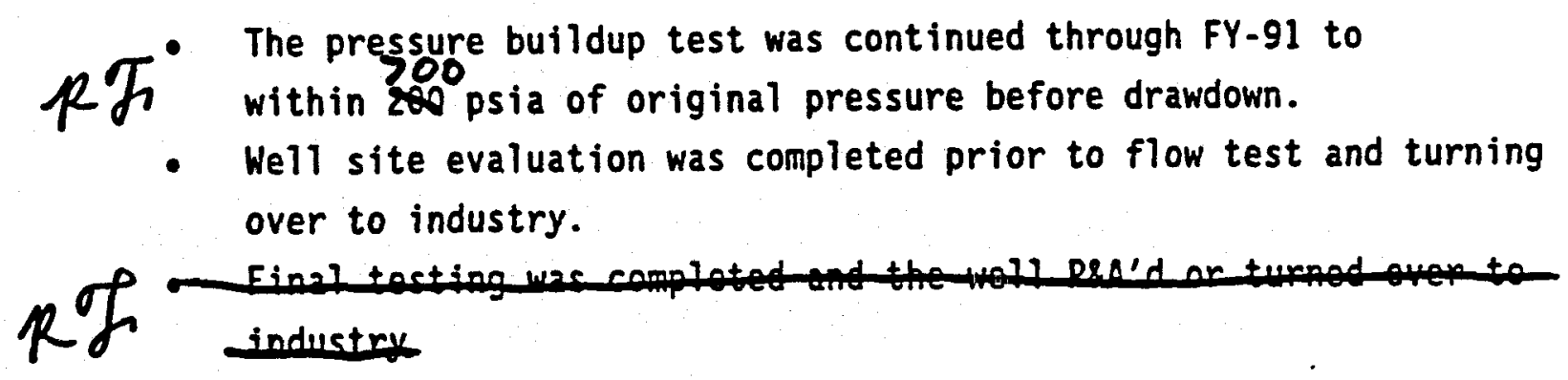

For the Hulin site in Louisiana. Significant accomplishments for FY-89, FY-90, and FY-91 are:

- Workover was completed. The well was put in a safe condition in preparation for flow testing.

- Short term initial test was run, and the disposal well completed. Samples were taken and the flow rate tested was about 5000 bpd. 
- The well was placed on standby and the facilities prepared for long term testing.

The general accomplishments are as follows:

- Eaton completed the final contract report for the first five years of the current DOE "Contractor for Geopressured-Geothermal Sites."

- Eaton has performed the operation with an excellent safety and environmental record. Through March 1991 of the fiscal year, there had been 15,877 man hours of work, with no lost time accidents.

- Construction of surface facilities for-long term flow testing was completed.

\subsection{Geoscience and Enqineering Support Task}

\subsubsection{Task Description and Overview:}

The geoscience and engineering support is focused on analyzing geopressured well data and understanding how geopressured-geothermal reservoirs respond to long-term, high-volume production. Reservoir analysis and the continuing refinement of the reservoir model will determine reservoir characteristics and drive mechanisms and ultimately allow the prediction of long-term production on the basis of short-term tests. Refinement of the geology at the well sites will delineate reservoir size and volume, information necessary for an accurate reservoir model. Deformation of the reservoir rock samples under in situ stresses in the laboratory will yield rock mechanics data also necessary for the reservoir model. This work has been completed. Accurate evaluation of logs is necessary for acquiring basic information such as salinity and porosity. This work has been completed. Researchers will examine the effects of rock stress, shale content, and wettability on rock resistivity, and the effects of trace elements on neutron logs. This work has been completed. The variation of cryocondensates with time will be measured for produced geopressured brine. This work has been 
completed. Environmental monitoring at the geopressured well sites and archiving of geopressured data and reports is continuing.

\subsection{2-3 Funding and Manpower:}

$\begin{array}{ccc} & \begin{array}{c}\text { Funding } \\ (\$)\end{array} & \begin{array}{c}\text { Manpower } \\ (\text { man/yr) }\end{array} \\ & 1,370 \mathrm{~K} & 11 \\ \text { FY-91 } & 465 \mathrm{~K} & 3\end{array}$

\subsubsection{Accomplishments:}

The Geoscience and Engineering Support accomplishments for FY-90 and FY-91 are as follows:

UTA-BEG:

- The FY 89 effort has been focused on compiling a preliminary hydrologic model in the depth interval equivalent to the Pleasant Bayou $\# 2$ well. Base map of pressure distribution in oil and gas fields in the vicinity of Pleasant Bayou and their alteration due to pressure depletion are being evaluated. The selection of production fields was guided by the geologic model which identified the location of major faults in the Pleasant Bayou area.

- Pressure-production history for Pleasant Bayou \#2 is being compiled for correlating pressure depletion with production. This could be used for material balance calculations and decline curve analysis for reserves estimation. This will also be matched with chemical data to see any changes in trends.

- Collocation studies of geopressured brine and oil on the Deep Wilcox reservoirs and the Jackson Group were initiated and completed. Extensive well data were obtained from Fanion 011 Company for the regional trends of the Deep Wilcox and Jackson Group Cole and Mirando sandstones. 
UTA-CES:

- Experimental apparatus was modified to measure three-dimensional rock mechanics parameters under three-dimensional stresses, which information will be needed to assess the production stability, especially in the vicinity of the wellbore, with continued fluid production from a geopressured reservoir.

- Illustrative values of water production for an example reservoir pressure change for a cubic mile of original reservoir rock were shown using pore water expansion; uniaxial compaction values; and pore volume compressibility values measured in the laboratory at insitu conditions.

- A review of geopressured-geothermal rock compaction mechanics has been initiated to develop a report for publication on creep studies.

- Designed, built, and installed internal axial displacement calibration assembly in Torsion Test apparatus.

- Obtained BOAST II Simulator from the Department of Energy Bartlesville Project office. The model has been modified to calculate well productivity.

The Logging Project accomplishments include the following:

- Designed and monitored data acquisition for logging program, DOE Hul in \#l Well.

- Carried out computer analysis (ELAN Program of new logs) from DOE Hul in Well in 1989, as well as ELAN analysis of open hole logs on this well obtained by Superior Oil Co. in 1978. 
- Gathered rock samples, cement samples, and cement additive samples to measure trace amounts of boron from West Texas formations. Boron analyses have been completed.

- A paper has been developed by Or. Henry Dunlap on the Evaluation of a Geopressured-Geothermal Reservoir.

UTA-S-Cubed:

- Developed a reservoir simulation model for the Pleasant Bayou resource based on synthesis of the following data: geologic studies by the Bureau of Economic Geology, laboratory rock mechanics measurements on core specimens by the UTA rock mechanics group, fluid properties measured in various laboratories, data from the 1988-90 testing of Pleasant Bayou Well No. 2, and S-Cubed's interpretation of the new flow test data in conjunction with downhole pressure measurements made during the 1990 Phase I flow test of the well. The simulation matches the production data to date; it has been modified and improved as indicated by new test data.

- A paper was published paper in the Journal of Energy Resources Technology regarding behavior of Gladys McCall reservoir during the 3.5-year depletion phase (October 7, 1983 to April 21, 1987). Behavior during the recovery phase is not matched by the model that matched the behavior during the depletion phase. S-Cubed is monitoring the pressure/temperature logging of Gladys McCall Well No. 1 during the on-going long-term shut-in test and performing a series of parametric reservoir simulations in an effort to determine the mechanism(s) responsible for the sustained pressure maintenance.

- S-Cubed prepared a formal topical report summarizing the results of the Gladys McCall reservoir through April, 1990.

- Scoping calculations for Willis Hul in Well No. 1. 
USL:

- Over 150 scrubber samples were picked-up on six visits to the Pleasant Bayou Well. The samples were returned to USL laboratory for analyses.

- A rapid, accurate system with high accuracy was developed to analyze the scrubber samples.

- Made precision measurements on the solubility of certain aromatic hydrocarbons and their distribution between a standard "oil" and water as a function of ionic strength and temperature. Specifically measurements were made for ethylbenzene and the isomers of xylene.

- The Pleasant Bayou Design Well was sampled on a monthly basis to determine the cryocondensate concentrations in the brine stream.

- A new sampling device designed to measure the benzene concentration in the gas stream on a daily basis was developed and installed at the Pleasant Bayou Well.

- The cryocondensate concentration in the brine stream at the Pleasant Bayou Well has been analyzed and compared with production models.

- The development of a harsh environment pH monitor based on ion-selective field effect transistor (ISFET) technology was shown to have excellent stability under pressures up to $\geq 6000 \mathrm{psig}$, and up to 3000 hours.

LSU:

- Maintenance of established systems for monitoring subsidence, seismicity, and water quality around test wells in Louisiana and Texas is continuing. Stations around Gladys McCall are scheduled to come down by the end of the FY-91 contract year pending completion of the final flow test. 
Microseismic monitoring:

- Monitoring is continuing at Pleasant Bayou and Hulin wells. New stations in closer proximity to the Hul in site are being established throughout the contract year. Currently (as of April 1990), three sites have been installed within $10 \mathrm{~km}$ of the well site. An additional station should be in place on Week's Island, located approximately $14 \mathrm{~km}$ southeast of the Hul in prospect, by middle summer 1990.

Water Quality Monitoring:

- Water quality monitoring is continuing at all three sites. Ground water and surface water samples are being collected and analyzed from each of the three prospect sites. Currently, sampling is being done on a quarteriy basis with chemical analysis being bid out to commercial laboratories. The Operating Company is now responsible for this work. DOE-ID is performing quarterly checks.

Subsidence Monitoring:

- Data from leveling surveys at Gladys McCall and Pleasant Bayou during FY-88 were analyzed. Leveling was performed in summer 1990 at the Hulin site on benchmarks installed in January 1989. No credible effects of geopressured-geothermal testing have been found. Anomalous changes in benchmark elevations around Pleasant Bayou are being further investigated. The Hul in Well levelling data have been received from the subcontractor and are being reviewed.

Geological Investigations:

- Excellent quality reflection seismic data was found for the Hul in area and purchase of approximately 22 miles was accomplished. A new seismic - structure map incorporating well log and othergeological data was completed for the Hul in prospect incorporating the new seismic data. 
- Evaluation of previously tested geopressured-geothermal prospects in Louisiana has been initiated in order to evaluate any relationship that might exist between geopressured-geothermal sand reservoirs and the association of free gas.

- Reports on collocation studies of geopressured reservoirs with oil in southern Louisiana and Texas were completed.

\section{Well Operations - General}

- Eaton completed the final contract report for the first five years of the current DOE "Contractor for Geopressured-Geothermal Sites".

- Eaton has performed the operation with an excellent safety and environmental record. Through June 1991 of this fiscal year, there had been 24,508 man hours of work, with no lost time accidents.

- All project Eaton-IGT employees have received 40 hours of hazardous materials handling training, CPR, fire safety, and first aid training.

- Establishing plans for environmental self-assessment at all three sites.

- Have conducted the yearly recalibration of all production gauges and relief valves at all sites.

- Eaton Deputy Program Director and Site Engineering and Testing Manager have current well control training.

- Have conducted quarteriy surface water sampling to ensure there has been no ground water contamination from operations.

\section{Gladys McCall Well}

- Revised conceptual model based on recovery data. 
- Performed series of parametric calculations to begin quantifying conceptual model.

- Model modified based on shut-in pressure buildup and bottomhole pressure data. Reservoir volume estimate increased to 8 billion barrels.

- Developed depositional model for Gladys MCCall geopressured sands.

- Concluded that environmental monitoring Gladys McCall has not shown any detrimental environmental effects attributable to the long term testing at Gladys McCall (microseismic, water quality, and subsidence).

- Site evaluation was completed prior to final testing.

- Completed Design Review with DOE-ID for the Gladys MCCall shortterm testing project.

Pleasant Bayou Well

- Measured time-dependence variation of the cryocondensates in geopressured reservoirs.

- Measured the solubility and distribution of aromatic compounds in brine.

- Established a preliminary reservoir model based on chemical analyses of fluids of the geopressured wells.

- Initiated long term flow testing.

- Completed workover of the injection well and initiated higher flow rates. 
- Eaton has operated the Pleasant Bayou production well over $99 \%$ of the available time for the fiscal year. Rates have been up to over 25,000 BPD.

- The scale inhibitor squeezes done on the Pleasant Bayou production well have been very successful. As of July, the well has produced $17,776,000$ barrels of brine, with no scale deposition in the well or in the surface production facilities.

- The corrosion treatment program at Pleasant Bayou has been very successful. There have been no corrosion failures in the fiscal year.

- Conducted an electrical self-assessment at Pleasant Bayou and corrected all deficiencies. This will also be done at the other two sites.

\section{Hul in Well}

- Developed depositional model for Hul in submarine channel sand or unstable shelf data.

- Completed difficult workover, completed preliminary short- term flow test. Well on standby.

- Completed difficult workover, completed preliminary short-term flow test. Well and facilities prepared for long term flow testing.

- Model of Hul in geology of being modified as a result of newly acquired seismic lines.

- Completed construction of surface facilities for long term flow testing. The boards were removed and the location "permatized" at the Hulin site. 


\section{Publications}

See Appendix A.

\subsection{Energy Conversion Task}

\subsubsection{Task Description and Overview:}

Geopressured-geothermal fluid contains chemical (methane), hydraulic and thermal energy. The methane, hydraulic energy and heat can be used to produce electricity. The methane can be sold to a pipeline, compressed or liquefied, or converted to methanol. The heat can be used to produce electricity or for direct use. If the methane is used for electricity production, then waste heat from its combustion can be utilized for increased energy efficiency in a hybrid power system, producing more electricity than separate power cycles using the same amount of gas and geothermal heat.

In cooperation with industry, construct and operate a hybrid 1-MWe power system for up to one year at the Pleasant Bayou site. Analyze operational data.

\subsection{2-3 Funding and Manpower:}

$\begin{array}{ccc}\begin{array}{c}\text { Funding } \\ \text { (SK) }\end{array} & \begin{array}{c}\text { Manpower } \\ \text { fman/yr) }\end{array} \\ \text { FY-90 } & 808 & 4 \\ & 1,000 & 5\end{array}$

\subsubsection{Accomplishments:}

The project is completed.

- Development of a hybrid power system test plan.

- Assured compliance with all DOE safety and environmental compliance issues. 
- Developed design and constructed design the hybrid power system.

- Completed successful eight months testing of the hybrid power system.

- Final report completed. Presentations were made at the GRC meetings. The EICEC meeting and program reviews. News releases were made as appropriate.

- Issued bids (August) for dismantling of the Hybrid Power System.

\section{Status}

Al1 operation and reporting has been completed.

The facility was dismantled in FY-1991.

\subsection{INEL Management}

\subsubsection{Task Description and Overview}

Supply technical and management support to DOE-ID on the Geopressured-Geothermal Program.

\subsection{2-3 Funding and Manpower}

\begin{tabular}{ccc} 
& $\begin{array}{c}\text { Funding } \\
\text { (SK) }\end{array}$ & $\begin{array}{c}\text { Manpower } \\
\text { (Man/Hrs) }\end{array}$ \\
\cline { 2 - 3 } FY 90 & 565 & 3.5 \\
FY 91 & 565 & 3.5
\end{tabular}

\subsubsection{Accomplishments}

- Presented paper on industrial participation at the Geothermal Program Reviews VII, VIII, and IX in San Francisco.

- Completed a paper on resource economics for DOE-HQ. 
- Completed four feasibility reports on Utilization;

1) Direct Use, 2) Thermal Enhanced Oil Recovery, 3) Use of SuperCritical Fluid Processes in Detoxification of Organic Wastes, and 4) Conversion of Hydrautic Energy.

- Continued organizing and conducting meetings of the Industrial Consortium on Resource Utilization $(9 / 89,1 / 90,9 / 90)$. Developed consortium brochures.

- Supplied technical and managerial program support to DOE-ID.

- Completed a special report on corrosion.

- Completed a special report on the HPS.

- Completed modification of the HPS test plan.

- Developed and issued 2 two-volume consortium proceedings sets and mailed to over 350 interested parties.

- Organized a seven paper session on the geopressured-geothermal resource for the geothermal resource council meetings in Hawaii.

- Presented papers on the Geopressured Reservoir and Utilization at the annual GRC meetings.

- Presented a paper on direct use at the GRC meetings.

- Presented papers on the Industriat Consortium at the Washington reviews.

- Presented papers on the four feasibility studies at the Washington review.

- Developed a review panel for university proposal review. 
- Presented a poster/paper session at The American Association of Petroleum Geologists (AAPG) at Dallas, Texas, with 6500 participants.
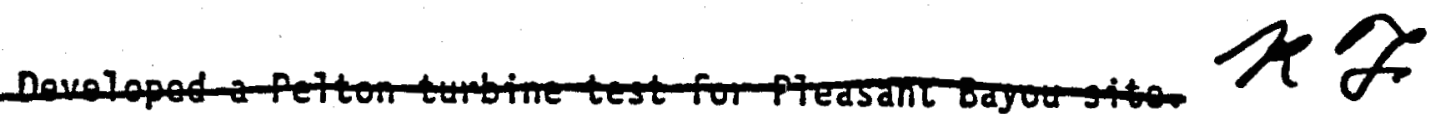

- Developed a joint proposal with Los Alamos National Laboratory on an evaluation unit for destruction of petroleum wastes by Supercritical fluid Processing using the geopressured resource.

- Prepared a Site Evaluation prior to final testing of Gladys McCall Well.

- Developed review panel to make recommendations for the future well testing and program direction.

- Presented a paper on Pleasant Bayou geology at the panel review.

- Developed a review committee for the operations proposals.

- Assisted in review of the Gladys MCCall Well test design.

- Completed a TETRAD reservoir model for the Pleasant Bayou Well.

- Completed the first draft of a paper on The Geopressured Habitat.

- Completed a 16-page color brochure on the Geopressured Resource.

- Presented a paper on the Geopressured Habitat and the brochure at the Program Review in Washington, D.C.

- Paper on TEOR accepted for the International AAPG meetings in London. 
เ

20 


\subsection{FUNDING YEAR RESEARCH PLAN}

\subsection{Project: Pleasant Bayou}

\subsubsection{Issue}

Reduce the cost of production of geopressured-geothermal energy. In addition, operational data from the flow testing of Geopressured Wells is needed to improve understanding and prediction of geopressured well behavior.

\subsubsection{Project Description}

There are several ways in which the cost of production in a geopressured well can be reduced. One of the primary ways is through a reduction in the number of operators through process automation. In addition, control of scale and corrosion can improve cost efficiency by improving brine flow rate and by reducing shutdowns. Increased experience in surface handling facilities can also impact the resultant energy cost.

\subsubsection{Statement of Work}

The Pleasant Bayou Well will be slow tested in FY-1992 with appropriate downdole pressure measurenents using calibrated logging tools, and a pressure buildup test, it indicated. The contractor will prepare to conclude the Pleasent Bayiv experionent.

3.1.4 Milestones

Monitor and evaluate surface facilities.

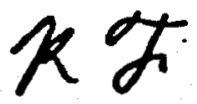

\subsubsection{Deliverables}

See Table 3.

3.1.6 Expected Accomplishments

obtain pressure buildup information.

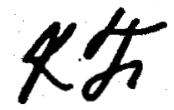


3.1.7 Funding Requirement

See Table 4.

3.1.8 Manpower Requirement

See Table 4.

3.2 Project: Haul in Reservoir

3.2.1 Issues

The HuI in Well is the deepest, hottest geopressured well in the program. It may have free gas in the top reservoir sands. The Hut in Well needs to be tested.

3.2.2 Project Description

Workover of the Haul in Well has been completed.

The entire

interval of interest needs to be perforated and flow testing initiated. Test planning beyond flow testing and future use of the Hut in resource needs to be addressed with a consensus for future work.

3.2.3 Statement of Work

The contractor will be directed to keep the Arlin well on standby status in FY 92. The contractor will conduct periodic site inspections and record readings of wellhead pressure gauges and other site instruments

3.2 .4 Milestones

NA

久タุ

3.2.5 Deliverables

See Table 3.

22 
3.2.6 Expected Accomplishments

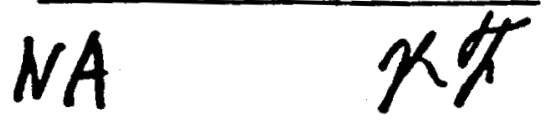

\subsubsection{Funding Requirement \\ See Table 4.}

\subsubsection{Manpower Requirement \\ See Table 4.}

\subsection{Project: Liquid Hydrocarbons}

\subsubsection{Issue}

Production of hydrocarbons from geopressured-geothermal DOE design wells has shown a relationship to flow rate in the geopressured wells. Research suggests that cryocondensates can be indicators of the geochemistry of the geopressured reservoir and possibly of the dynamics of the reservoir production.

\subsubsection{Project Description}

Complete assessment of hydrocarbon occurrence as a marker in geopressured brines. A final report will be written summarizing the many years of DOE supported work in this area and the project will be closed out. This will be performed by USL.

\subsubsection{Statement of Work}

Complete a topical $\Lambda$ report summarizing work to date in these areas: Cryocondensate in brine, amounts, types vs. brine volume produced, and vs. brine rate. This report should be focused at drawing conclusions from analyses done to date on assessment of hydrocarbon occurrence at a marker in geopressured brines. If flow testing is initiated at Hulin, the hydrocarbons will be measured, analyzed, and interpreted. As the Pleasent Bayou well is slow tested the contractor will take hydrocarbon samples and perform the appropriate meesurements and andyses on them.

3.3.4 Milestones

Completed final reports. 


\subsubsection{Deliverables}

See Table 6.

\subsubsection{Expected Accomplishments}

final report completed.

\subsubsection{Funding Requirement \\ See Table 4.}

\subsubsection{Manpower Requirement \\ See Table 4.}

\subsection{Project: Reservoir Engineering}

\subsubsection{Issues}

The well test data needs to be analyzed, synthesized, and integrated with pertinent related research. Integrated reservoir data needs to be utilized to improve and evaluate existing reservoir simulation for geopressured-geothermal wells. The evolving model must be validated, through examination of data, conceptual models, and methods of simulation.

Geologic studies need to be conducted on reservoirs for the operational wells to provide specific integrated data for reservoir simulation; integration of geoscience data is needed to improve understanding of the geopressure-geothermal reservoirs.

\subsubsection{Project Description}

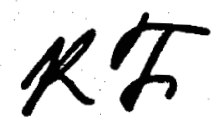

Fnterptet Reservoir Engineering data. This task involves taking flow data from the well sites and interpreting it with models developed by progran researchers. The work will be performed by S-Cubed, INEL and LBL.

\subsubsection{Statement of Work}

In FY-1992, the reservoir engineering researchers will interpret reservoir engineering dota. The task includes taking fiow data from the 


\section{computer}

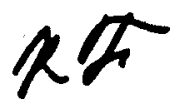

well sites and interpreting it with models developed by pragram researchers at S-Cubed, INEL, and LBL.

\subsubsection{Milestones \\ Completed final reports.}

\subsubsection{Deliverables}

See Table 3.

\subsubsection{Expected Accomolishments}

Final reports completed.

\subsubsection{Fundina Reouirement \\ See Table 4.}

\subsubsection{Manpower Requiremen:}

See Table 4.

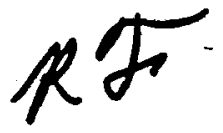

3.5 Project Vertical Seismic Profile at Pleasant Bayou site

\section{5 .1 1ssues}

The ultimate goal of reservoir modeling is the determination of reservoir volumes, drive mechanisms, and productivity; thus providing industrial, financial, and governmental entities with data for invesiment, utilization, and policy decisions. The determination of the nature and location of geopressured reservoir boundaries by seismic methods can serve as powerful constraints on reservoir models.

Vertical seismic profiling is a relatively inexpensive seismic technique which involves placing a seismometer (receiver) in the well at some depth which records the arrival time of seismic pulses generated by a source at surface. Vertical seismic profiling (VSP) can yield high resolution data of immediate use in the description of geopressured reservoirs with potential future benefits in the processing and acquisition of seismic profiling data. 


\subsubsection{Project Description}

A four direction survey will be used to delineate the reservoir in three dimensions in the vicinity of the well. The proper acquisition, processing, and interpretation of the VSP data will require the integration of existing seismic, reservoir, well log, geologic, and rock mechanics data.

3.5.3 Statement of Work

Resediehers will conduct a will search for seismic, reservoir, well log, geologic, and rock mechanics data pertinent to the design of the VSP experiment. They will also interpiet the experiment results. Wavelet processing will' include velocity modeling, well-log processing, postmigration-wavelet processing, and seismic inversion. Data interpretation will involve the inversion of seismic data to derive seismic velocity, density, overburden pressure, and formation-pressure logs for comparison with drill stern tests and sonic, density, porosity, or other well logs that may serve as point sources of formation pressure data. High resolution will also be obtained with processing techniques including pattern recognition using multi-variate statistical analysis, principal component analysis using the Karhunen-Loeve Transform, high resolution velocity analysis using a signal detection algorithm based on covariance. and amplitude variation with offset. The direct detection of a gas cap will also be investigated with amplitude variation with offset.

\subsubsection{Milestones}

Compieted final reports.

\subsubsection{Deliverables}

See Table 3.

\subsubsection{Expected Accompl ishments}

Final reports completed.

\subsubsection{Funding Requirements}

See Table 4. 


\subsubsection{Manoower Requirement}

See Table 4.

\subsection{Project Environmental Effect}

\subsubsection{Issue}

Environmental monitoring needs to be continued at the geopressured-geothermal well sites in Louisiana and Texas. Environmental components that the well tests are likely to effect were previously identified and a monitoring program was instituted.

\subsubsection{Project Description}

Acquisition of pretest baseline data. data curing testing, and post-test monitoring data to assure there are no adverse long term effects. Continue theoretical work to fit monitoring results to modeis of the

geopressured-geothermal reservoirs and the surrounding geological formations. This work will be performed by LSU.

\subsubsection{Statement of Work}

Microseismic monitoring:

Monitoring will continue for evidence of induced microseismic activity at Pleasant Bayou and Hulin wells. Efforts to interpret the recorded signals also will continue.

Water Quality Monitoring:

Water quality monitoring will continue at all three sites. Ground water and surface water samples will be collected and analyzed as in previous years. All water sample collecting and analysis will be the responsibility of the operating company. Rubidium and lithium will be included in the list of analyzed constituents as they are commoniy found in Gulf coast brines and should serve as good indicators of brine contamination of ground water or surface water. 
Subsidence Monitoring:

Subsidence monitoring will continue at Pleasant Bayou and Hul in sites.

\subsubsection{Milestones}

Microseismic monitoring continued at the Pleasant Bayou and Hulin wells.

Water quality monitoring continued at all three sites (operating company).

Integration continued of site specific data with regional leveling data.

3.6.5 Deliverables

See Table 3.

\subsubsection{Expected Accomplishments}

Continued monitoring subsidence, seismicity, and water quality (operating company) around Pleasant Bayou and Hul in wells in Louisiana and Texas for FY-92. Water quality monitoring will be continued around the Gladys McCall site.

\subsubsection{Funding Requirement \\ See Table 4. \\ 3.6.8 Manpower Requirement \\ See Table 4.}

\subsection{Project: Strategies for Resource Utilization}

\subsubsection{Issues}

The petroleum geochemistry relationships to geopressured compartments and physics and chemistry constraints of the geopressured-geothermal resource need to be understood and made available to the industrial community to assist 
them in commercial utilization. This includes hydrocarbon maturation and occurrence under temperature and pressures of the geopressured reservoirs, effect of total dissolved solids on gas saturation, geological trends in temperature and pressure, dissolved solid concentrations and hydrocarbons, and expected recharge causes and rates in the Gulf Coast reservoirs.

\subsubsection{Project Descriotion}

A review study of the geopressured habitat, occurrence, geological and geochemical attributes, hydrocarbon association, and reservoir response to production will provide a basic tool for understanding and decision making on the part of industrial entrepreneurs interested in utilizing the geopressured resource. These aspects have not been pulled together synthesized, and interpreted in program research. The relationship of hydrocarbon maturation to the development of geopressured compartments and implications to recharge and reservoir life expectancy will be examined in the context of geopressure as a phase in the evolution of basinal development where organic source material is available.

\subsubsection{Statement of Work}

The Idaho National Engineering Laboratory (INEL) will complete development of a geopressured-geothermal resource review to include the physics, chemistry, geology, hydrocarbons, and reservoir response associated with the production. This review will include synthesis and interpretation of research within the program and related published research outside the program. INEL will develop and apply the geopressured habitat study to a geologic reservoir model in support ${ }_{n}^{\circ}$ reservoir simulation effort.

\subsubsection{Milestones}

Complete peer reviewed report on the geopressured resource for publication in a recognized journal. Present peer reviewed paper at appropriate society meeting and modify according to reviews and response. Complete geologic reservoir model for reservoir simulation.

\subsubsection{Deliverables See Table 3.}




\subsubsection{Expected Accompli ishments}

Completed peer reviewed report on the geopressured resource for publication in an appropriate journal and make report available to industry. Complete geologic reservoir module for reservoir simulation.

\subsubsection{Funding Requirement See Table 4.}

\subsubsection{Manpower Requirement} See Table 4.

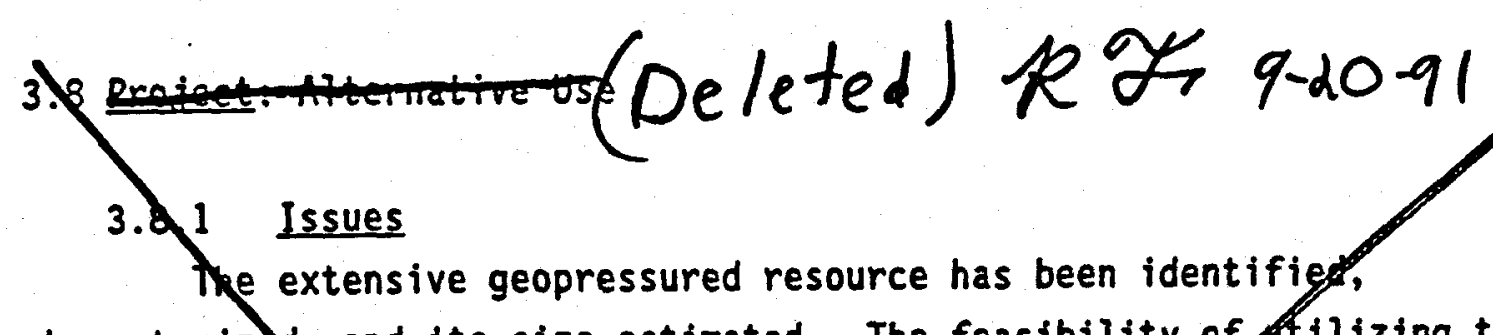
characterize, and its size estimated. The feasibility of ftilizing the gas, hydraulic, and thermal energy has been studied. The acflal utilization of the resource needs th be demonstrated and evaluated for houstry. Direct use projects, cost-share by industry and state fund can implement transition to commercial use of the hesource for the benefiy of the United States.

\subsubsection{Project Description}

DOE-ID will award a contract for Geopressured Utilization in FY-1992.

The contract is estimated to be year contract with a minimum of $65 \%$ industry cost share. The totgh cost of the contract over the 3 years is anticipated to be $\$ 4.5$ milyon.

\subsubsection{Statement of Work}

DOE-ID wiy award a contract for Geopressured Utilization following an RFP solicitatiof. The project will be implemented in FY-1992.

\subsubsection{Milestones}

Complete contract award.

Initiate project. 


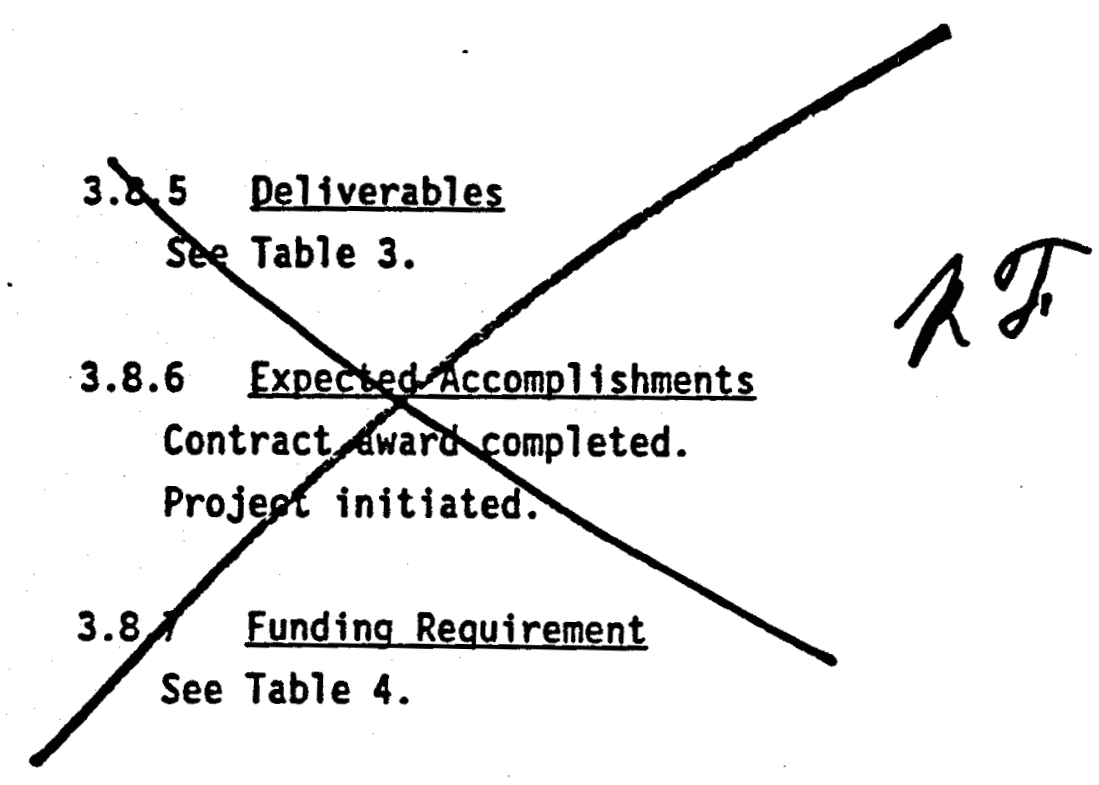

3.9 Project: INEL Management/Technical Support/Technical Transfer

\subsubsection{Issues}

Technical and managerial support to DOE-ID is needed in the areas of technical expertise, specific investigations, day-to-day project management, litigation, and program $p l a n n i n g$ and development.

\subsubsection{Project Description}

Support to DOE-ID will be provided by EG\&G/INEL in the following areas:

Long Range Planning,

Preparation of AOP,

Preparation of Reports,

Overall Program Budget Analysis,

Preparation of Test Plans and Work Scopes,

Quality and Safety Review of Testing Operations,

Assistance in Program Management,

Technical Monitoring and Support of University research efforts,

Assistance in the Transfer of Technical Data to the Industrial

Arena, and Procurement of Special Services or Equipment.

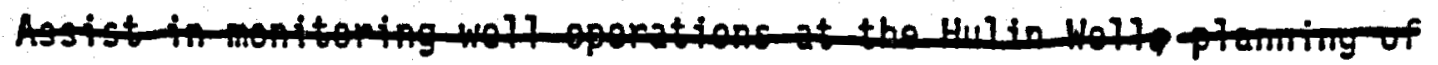


coordination, and technical support of reservoir engineering. Development of an industry review committee.

\subsubsection{Statement of Work}

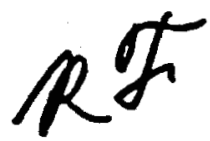

The INEL will support researchers and DOE in their effort to prepdre the present program for completion. This will involve researcher oversight, assistance with final environmental assessments at well sites, and completion of a formal technical report summarizing the results of research to date conducted by the Geopressure Program.

Specific documents and tasks include the following:

Plan to bring the program to a conclusion.

Prepare AOP.

Prepare program reports.

Analyze overall program budget.

Prepare test plans and work scopes.

Review quality and safety. of testing operations.

Assist in day-to-day program management and provide a DOE presence at the University and operations sites on a monthly basis.

Provide technical monitoring and support of University research efforts.

Assist in the transfer of technical data to the industrial arena.

Procure special services or equipment.

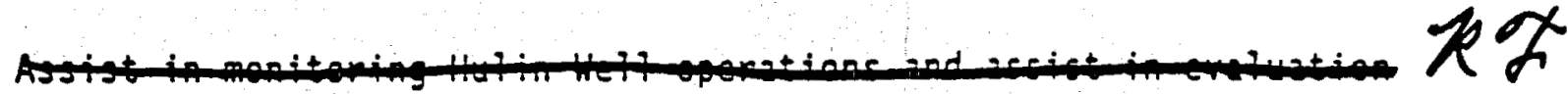

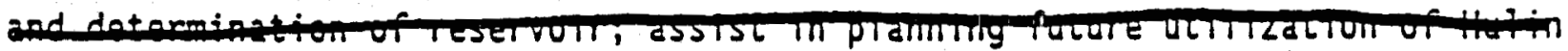

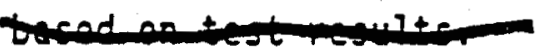


Provide coordination, integration, and technical support (in reservoir predictability) to the Reservoir Engineering.

\subsubsection{Milestones}

Long Range Research planned.

AOP prepared.

Program reports prepared as required: GRC Meeting, Program Reviews, Geothermal Program Review, Industrial Consor:ium Presentations.

Monthly Report: overall program bucget analyzed, twice a year and monthly tracking, day-to day management provided in FY-90 and technical monitoring and support of and support of University research efforts provided.

- Test plans and work scopes prepared. On-going review carried out on Quality and Safety of Testing Operations.

Assistance provided in the transfer of technical data to the industrial arena (Industrial Consortium).

Special services and equipment procured as needed.

Coordination, integration, and technical support to the Reservoir Engineering project provided. 


\subsubsection{Deliverables}

See Table 36.

3.9.6 Expected Accomplishments

Completion of long range research plans.

Completion of AOP preparation.

Program reports completed.

Budget for overall program analyzed.

Preparation of test plans and work scopes completed.

Quality and safety review continued.

Day-to-day management and technical assistance provided in FY-1992.

\subsubsection{Funding Requirements}

See Table 4.

\subsubsection{Manpower Requirements \\ See Table 4.}




\subsection{MANAGEMENT PLAN}

\subsection{Overview of Management System}

The responsibility for management of the DOE Geopressured-Geothermal Program is that of DOE-ID with support from INEL.

Thomas Williams with DOE-ID is the contract Technical Director and Program Coordinator. Ken Taylor with DOE-ID is Project Manager for the operations area and for the research area. Directives to INEL, the well operating company, and the universities come from Thomas Williams and Ken Taylor.

The day-to-day management of the Geopressured-Geothermal Program is the responsibility of DOE-ID with support from the EG\&G, Idaho Inc. at INEL, Idaho Falls, Idaho. The Program Coordinator is Dr. Jane Negus-de Wys who monitors, tracks, coordinates and integrates the research. She visits the research facilities and coordinates visits to well operations; she contacts the principals in research at least once a week, and the operations office. Weekly Significant Events are reported; and a Monthly Progress Report is submitted with reports on research and operations. Well operations are monitored daily. One review per year with DOE-HQ is held, at which the principal research operations and management are represented.

A research proposal review committee has been developed to review the program $p l$ an and the university proposals. In addition, EG\&G/INEL provides daily technical support to DOE-ID and to DOE-HQ as requested. In-depth technical effort and consulting is sought and supplied as needed. Special reports are developed as needed or requested. 
4.2 Management Structure

\begin{tabular}{|c|c|c|}
\hline $\begin{array}{l}\text { DOE Headquarters: } \\
\text { Director, Geothermal Technology } \\
\text { Division }\end{array}$ & Dr. J. Mock & $\begin{array}{r}\text { (202) } 586-5340 \\
\text { FTS } 896-5340 \\
\end{array}$ \\
\hline Team Leader, Geoscience & Dr. Alan Jelacic & $\begin{array}{r}\text { (202) } 586-6054 \\
\text { FTS } 896-6054 \\
\end{array}$ \\
\hline $\begin{array}{l}\text { Program Manager, Geopressured } \\
\text { (excluding Conversion) }\end{array}$ & Ray Fortuna & $\begin{array}{r}\text { (202) } 586-1711 \\
\text { FTS 896-1711 } \\
\end{array}$ \\
\hline Team Leader, Conversion Technology & Dr. Dave Lombard & $\begin{array}{r}(202) \quad 586-4952 \\
\text { FTS } 896-4952 \\
\end{array}$ \\
\hline $\begin{array}{l}\text { Program Manager } \\
\text { Geopressured Conversion }\end{array}$ & Raymond LaSala & $\begin{array}{r}(202) \quad 586-4198 \\
\text { FTS } 896-4198 \\
\end{array}$ \\
\hline Program Manager, Direct Use & Nick Lilas & $\begin{array}{r}\text { (202) } 586-8021 \\
\text { FTS } 896-8021 \\
\end{array}$ \\
\hline DOE-ID: & & \\
\hline $\begin{array}{l}\text { Program Coordinator, IDO } \\
\text { Advanced Technology Division }\end{array}$ & Thomas E. Williams & $\begin{array}{r}\text { (202) } 526-0577 \\
\text { FTS } 583-0577 \\
\end{array}$ \\
\hline $\begin{array}{l}\text { Program Manager, Geopressured- } \\
\text { Geothermal Program } \\
\text { Advanced Technology Division }\end{array}$ & Ken Taylor & $\begin{array}{r}\text { (208) } 526-9063 \\
\text { FTS } 583-9063\end{array}$ \\
\hline Contractors: & & \\
\hline INEL Program Manager & Dr. J. Negus-de Wys & $\begin{array}{r}(208) \quad 526-1744 \\
\text { FTS } 583-1744 \\
\end{array}$ \\
\hline UTA Project Leader & Dr. Mark Miller & $\begin{array}{rr}(512) & 471-3250 \\
\text { FTS } & 471-3250 \\
\end{array}$ \\
\hline USWL Project Leader & Dr. John Meriwether & $\begin{array}{r}(318) \\
231-6691 \\
\text { FTS } 231-6691 \\
\end{array}$ \\
\hline LSU Project Leader & Dr. Chacko J. John & $\begin{array}{r}(504) \quad 388-8681 \\
\text { FTS } 388-8683 \\
\end{array}$ \\
\hline Well Operating Company & To be determined. & \\
\hline
\end{tabular}


Management Structure Diagram:

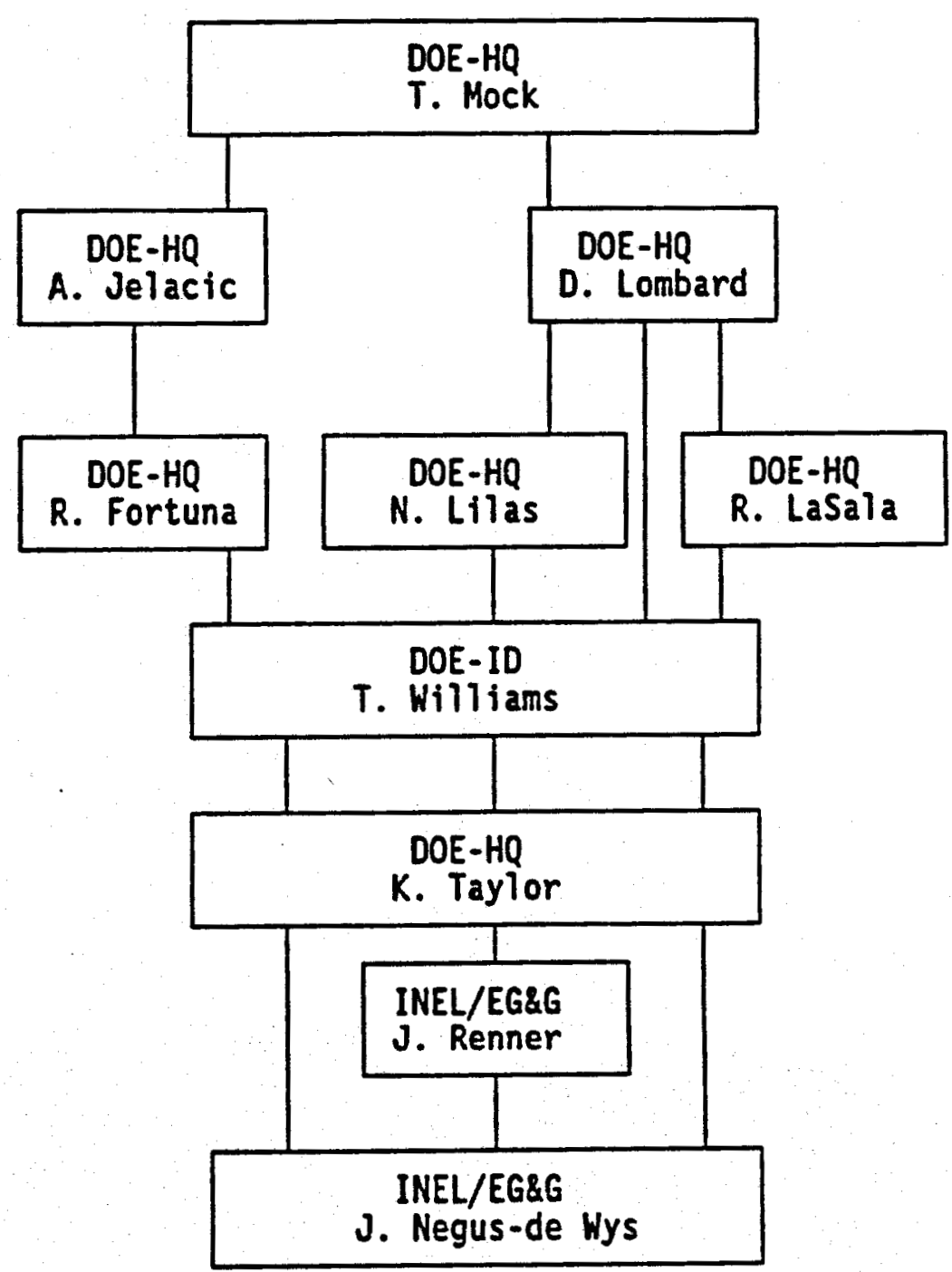




\subsection{Management Resource Requirements}

Management (INEL, operating company, S-Cubed, University and

Environmental) for the entire program requirement for FY-1992 is 2.0 FTEs.

\subsection{Procurement Plan Summary}

DOE has gone out with an RFP for a well operations contractor and has reviewed the responses with an Advisory Committee. This five year contract was awarded in the summer of 1991. This activity will follow the guidelines for such bids within EG\&G and in accordance with the U.S. Government subcontracting regulations.

\subsection{Subcontracting Plan}

- The operating company subcontracts a part of surface facility operation. The new contract award for well operations is not known at the time of this writing.

- INEL subcontracts, as needed, Dr. Hank Coffer or other selectees for specific technical support, and technical advisors for proposal review, and for advisory panels.

\subsection{Schedules of Conferences and Technical Reviews}

- Meeting of the Industrial Consortium on Geopressured-Geothermal Resource Utilization (Spring 92).

- Research integration and review-semi annually.

- American Association of Petroleum Geologists (6/21-24). (Sections related to geopressure-geothermal)

- Society of Petroleum Engineers (Spring 1992).

- Geothermal Resource Council meeting. 
- Geothermal Program Review (4/15/92).

4.7 Schedule of Planned Foreign Travel

International Meeting of the American Association of Petroleum Geologist: London, England $(9 / 27-10 / 3)$. Paper on TEOR accepted. 


\subsection{OUTYEAR RESEARCH PLAN (FY-92 through FY-94)}

\subsection{Goals/Objectives}

The basic present Geopressured-Geothermal Program will be brought to a completion in FY-1993, with environmental activities continuing through FY1995. The final deliverables are the following:

- Well Data

- Reservoir Model

- Summary Report on the Geopressured Resource

- Final Technology Report and Papers

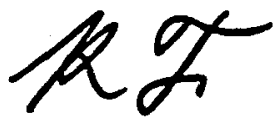

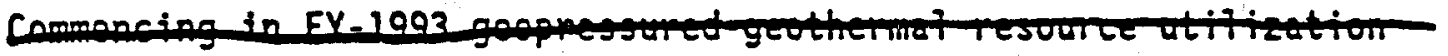

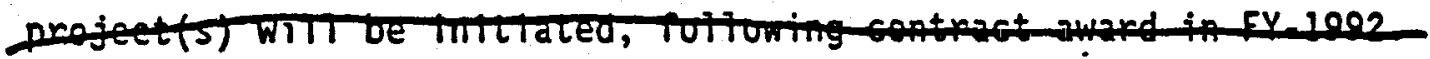

FY-1992-1993

Operation of the Pleasant Bayou Well will be terminated after the reservoir pressure decline is established and a scientific program of variable flow rate testing, diagnostic logging, geochemistry analysis, cryocondensate analysis, downhole pressure measurements, and sidehole coring is completed. Following the scientific experiments, the well will be plugged and abandoned.

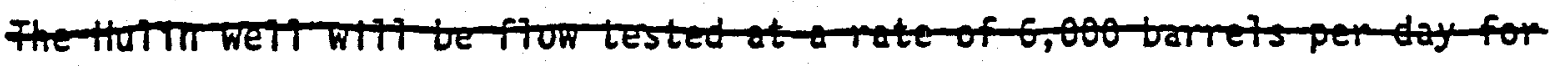

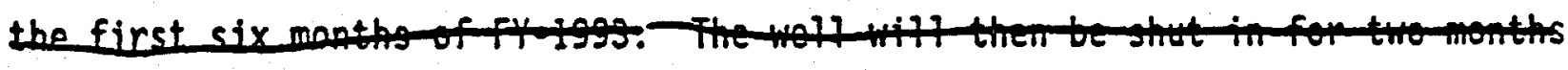

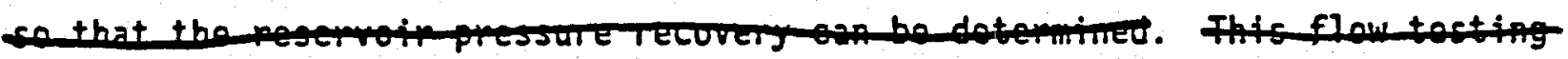

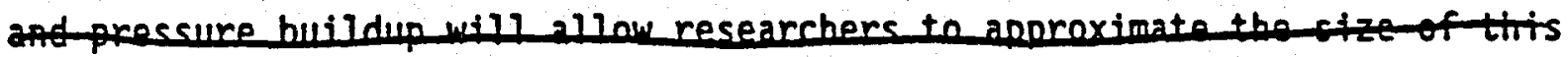

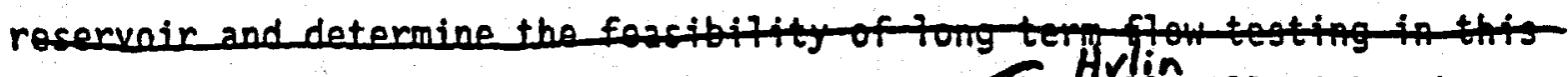
following tho the Hesting will either be passed to industry or Plugged and Abandoned.

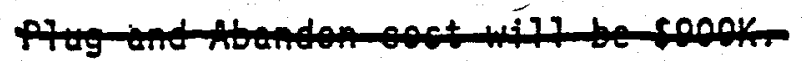

The supporting research program will be concluded, final reports written on all tasks and a final reservoir models completed. A complete final report summarizing the Geopressured-Geothermal Program will be written and industry coordination meetings will be held. 
Final deliverables will include:

- Well Data

- Reservoir Model

- Summary Report on the Geopressured Resource

- Final Technology Report and Papers

\section{2 - 5.3 Key Issues, Strategy, and Broad Task Descriptions}

The key issues and strategies are:

\subsubsection{Issue}

Production of geopressured fluid in commercial quantities requires long-term flow rates of 20 to 40 thousand barrels per day per well. These fluids must be disposed of in an environmentally safe manner.

\subsubsection{Broad task description and strategy}

Inject fluids from geopressured design wells into relatively shallow normally-pressured injection wells. Monitor injection well pressure for changes affecting the ability of the injection zone to accept fluids.

\subsubsection{Issue}

Full-time operators are presently required for surface brine handling. Surface facilities at both the Gladys McCall and Pleasant Bayou design well sites have shown susceptibility to corrosion and erosion. Once operational problems are brought under control, geopressured facilities should be able to function without continuous observation.

\subsubsection{Broad task description and strateay}

Instrumentation and control companies will design and verify automated control systems for the production of brine, separation of gas, and disposal of spent brine. Verify operation of automated systems with field tests. 


\subsubsection{Issue}

The mechanisms driving the production of geopressured-geothermal fluids are $i l l$-defined. Without knowledge of how and when these mechanisms function, the reliability of geopressured-geothermal reservoirs will remain uncertain. Confident predictions of reservoir productivity will enable better estimates of economic viability.

\subsubsection{Broad task description and strateay}

Continue production tests at the Pleasant Bayou design well, make Incorporate reservoir data into numerical reservoir simulator. Analyze reservoir stress state for the design well reservoirs using an improved geological reservoir model, rock compressibility, and reservoir pressure data. Model the test results to ascertain the presence of one or more theoretically-possible drive mechanisms.

Integrate the knowledge gained about reservoir measurements, models, and drive mechanisms into reservoir testing guidelines suitable for industry use.

A verification of extant technology could be accomplished at the Hul in Well. This well was drilled by industry through several geopressured-geothermal zones. Verification would be measured by the ability to predict brine quality. and longevity from logs and a short-term flow test.

\subsubsection{Issues}

Numerous oil and gas wells penetrate geopressured horizons, but the operators seldom evaluate the geopressured resource potential. Simplified, inexpensive means of evaluating that potential would increase the likelihood of resource production from wells of opportunity.

\subsubsection{Broad task description and strategy}

Routine geological information (e.g., logs, geophysical surveys, cores, fluid samples) is available for most Gulf Coast wells. Synthesize that information in such a way that geopressured resources may be identified and evaluated more readily. Develop well-logging techniques which in conjunction 
with existing geology and geophysical techniques permit the location and evaluation of potentially economic geopressured-geothermal resources. Study the effect of rock stress, shale content, and wetability on rock resistivity, and determine the effect of trace elements on neutron logs to improve the interpretation of logs from geopressured wells. Stress reservoir core samples to determine basic rock properties at in situ conditions. The techniques will be combined into a standard procedure that operators can use during or immediately after drilling operations to indicate resource potential.

\subsubsection{Issue}

The removal of large volumes of fluid from deep reservoirs may cause surface subsidence while the injection of fluid may cause uplift and induce earthquakes. Leaking surface equipment or well casing could contaminate fresh surface and ground waters.

\subsubsection{Broad task description and strategy}

Monitor surface subsidence, induced seismicity, and water quality in aquifers above the injection zones and in surface waters. Develop a model for reservoir compression which can verify whether adverse environmental effects will occur from the planned production and disposal methods over a ten-year period of operation.

\subsubsection{Issues}

The issues for the FY-1993 - FY-1994 Outyear Research Plan are:

- Reservoir predictability

- Economics/Automation

- Industrial participation in geopressure-geothermal energy utilization.

- Confidence/Reliability

- Materials selection/compatibility
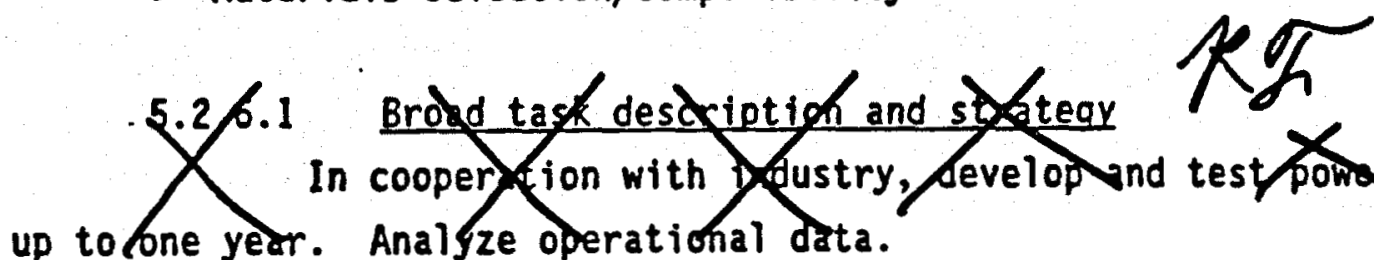

up to fone year. Analyze Operational data. 
5.4 Funding Requirements

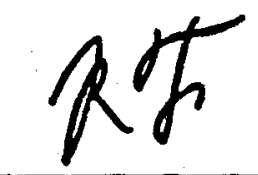

\begin{tabular}{|c|c|c|c|}
\hline & FY-92 & FY-93 & FY-9 \\
\hline Well Operations & & 1,700 & 0 \\
\hline $\begin{array}{l}\text { Geoscience and Engineering } \\
\text { Support }\end{array}$ & 895 & 1,000 & 500 \\
\hline Energy Conversion & 0 & $\mathbf{0}$ & 0 \\
\hline HBU & 0 & 0 & 0 \\
\hline $\begin{array}{l}\text { Management and Technical Support } \\
\text { and Tech Transfer }\end{array}$ & 370 & 365 & 300 \\
\hline Other Research & 150 & 0 & 0 \\
\hline 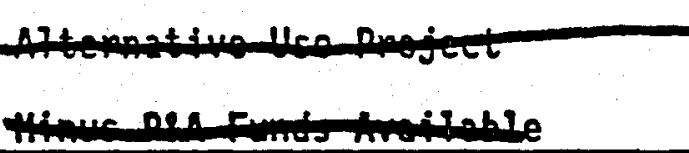 & 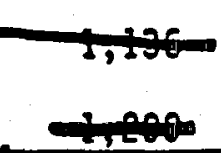 & 2,000 & 2,000 \\
\hline TOTAL & 1000 & 5,065 & 2,800 \\
\hline
\end{tabular}

\subsection{Manpower Requirements}

\begin{tabular}{|c|c|c|c|c|}
\hline & FY-91 & FY-92 & FY-93 & FY.94 \\
\hline Well Operations & 3.5 & 3.5 & 1.5 & 0 \\
\hline $\begin{array}{l}\text { Geoscience and Engineering } \\
\text { Support }\end{array}$ & 8.8 & 2.75 & 8.8 & 0 \\
\hline Energy conversion & 0.5 & 0 & 0 & 0 \\
\hline $\begin{array}{l}\text { Management Support and Tech } \\
\text { Transfer }\end{array}$ & 2.5 & 2.5 & 2.5 & 2.0 \\
\hline Other Research & 0 & 0.25 & 0 & 0 \\
\hline Alternative Use Project & 0 & $\pi 3.0$ & 4.0 & 4 \\
\hline TOTAL FTES & 15.3 & 12.0 & 16.8 & 6.0 \\
\hline
\end{tabular}


Table 1. FY-92 Milestone Sumnary.

\begin{tabular}{|c|c|c|c|c|c|c|c|c|c|c|c|c|}
\hline & 0 & $N$ & D & J & $F$ & H & A & M & $\mathrm{J}$ & $\mathbf{J}$ & A & $s$ \\
\hline \multicolumn{13}{|l|}{ Pleasant Bayou } \\
\hline Hulin & $c_{1}$ & & & $c_{3}$ & & & & & & & & \\
\hline \multicolumn{13}{|l|}{ Other location } \\
\hline $\begin{array}{l}\text { Supporting Research } \\
\text { and Analysis }\end{array}$ & $K_{1}$, & $k / 2$, & & & & & & & $K_{4}$ & & & \\
\hline DOE-HQ Review & & & & & & $R_{1}$ & & & $R_{2}$ & & & \\
\hline
\end{tabular}

\section{Control Milestones}

$C_{1}$ Complete high rate flow testing at Pleasant Bayou.

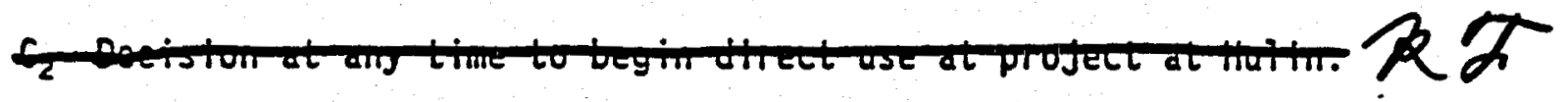

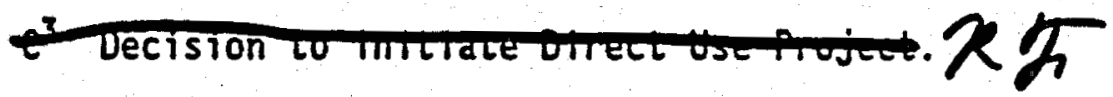

\section{Key Milestones}

$K_{1}$ Decision at any time to inject a pill at scale inhibitor or to shutdown for data acquisition.

$K_{2}$ Dectstollon

$K_{3}$ Review research integration and status of computer modeling.

$K_{4}$ Begin planning/preparation of FY-1993 AOP. 
DOE-HQ Review

$R_{1}$ February Program Review at DOE-ID

$R_{2}$ July Program Review at DOE-HQ, Washington, D.C.

Table 2. Overall Outyear Schedule and Control Milestones. Geopressured-Geothermal Tasks

\section{FY-92 FY-93 FY-94 FY-95}

\begin{tabular}{lccc} 
Pleasant Bayou & $C_{1}, C_{6}$ & $C_{5}$ \\
Hulin & $C_{2}, C_{3}, C_{4}, C_{6}$ & $C^{5}$ \\
Other location projects & $C_{7}$ & $C_{8}$ & \\
\hline
\end{tabular}

Milestone No. and Description

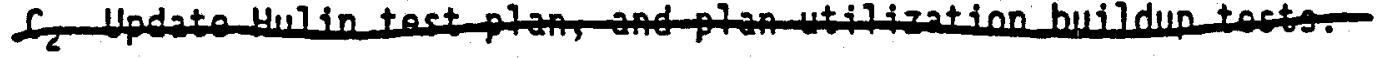

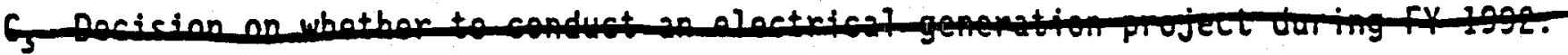

$C_{4}$ Decision to transfer well to industry or to plug and abandon Hul in Well (1992).

$C_{5}$ Decision to stop environmental monitoring.

$C_{6}$ Final Hul in Report.

$C^{7}$ Initiate Utilization Project in new area.

$c^{8}$ Final Use Report. 
Table 3. Deliverables Summary

\begin{tabular}{|c|c|c|c|}
\hline $\begin{array}{l}\text { QUARTERLY/ } \\
\text { MONTH } \\
\text { All research } \\
\text { contractors (UTA- } \\
\text { BEG, USL, and LSU) } \\
\text { will submit } \\
\text { quarterly progress } \\
\text { reports including } \\
\text { progress status, } \\
\text { accomplishments, } \\
\text { oral and written } \\
\text { presentations and } \\
\text { publications, } \\
\text { travel and } \\
\text { expenses. These } \\
\text { reports should be } \\
\text { received at DOE- } \\
\text { ID/EG\&G by the 15th } \\
\text { of the month } \\
\text { following quarterly } \\
\text { report. The Well } \\
\text { Operating Company } \\
\text { will submit a } \\
\text { monthly progress } \\
\text { report including } \\
\text { the stipulated } \\
\text { information above. }\end{array}$ & $\begin{array}{l}\quad \text { ANNUAL } \\
\text { The Annual Report } \\
\text { concentrating on } \\
\text { accompl ishments } \\
\text { (research } \\
\text { operations, and } \\
\text { publications with } \\
\text { budget summary will } \\
\text { be submitted by } \\
\text { contractors no } \\
\text { later than November } \\
\text { l, } 1992 \text {. An } \\
\text { overview, } \\
\text { comprehensive } \\
\text { annual report will } \\
\text { be submitted by } \\
\text { EG\&G by January } 1 \text {, } \\
\text { l993. }\end{array}$ & $\begin{array}{l}\text { RESEARCH PAPERS } \\
\text { PRESENTATIONS } \\
\text { ANALYSES/DATA } \\
\text { Copies of research } \\
\text { presentations and } \\
\text { publications will } \\
\text { be submitted prior } \\
\text { to or very shortly } \\
\text { after } \\
\text { presentations or } \\
\text { publication. } \\
\text { Analyses, well } \\
\text { monitoring and } \\
\text { environmental data } \\
\text { will be routinely } \\
\text { collected and } \\
\text { submitted as } \\
\text { scheduled. }\end{array}$ & $\begin{array}{l}\text { REQUESTS/REVIEW } \\
\text { CONTRIBUTIONS } \\
\text { Unspecified } \\
\text { analyses, reports } \\
\text { or advisory } \\
\text { documents shall be } \\
\text { supplied by the } \\
\text { contractors as } \\
\text { requested, within } \\
\text { reason. Two DOE-HQ } \\
\text { reviews shall be } \\
\text { attended, to which } \\
\text { contractors will } \\
\text { contribute as } \\
\text { required. }\end{array}$ \\
\hline
\end{tabular}


Management Structure Diagram:

Table 4. Funding and manpower by project and sontractor

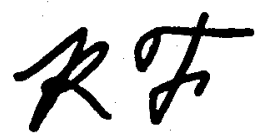
$(\$ 5,000 \mathrm{~K}$ Budget $-\$ 4,400 \mathrm{Net})$

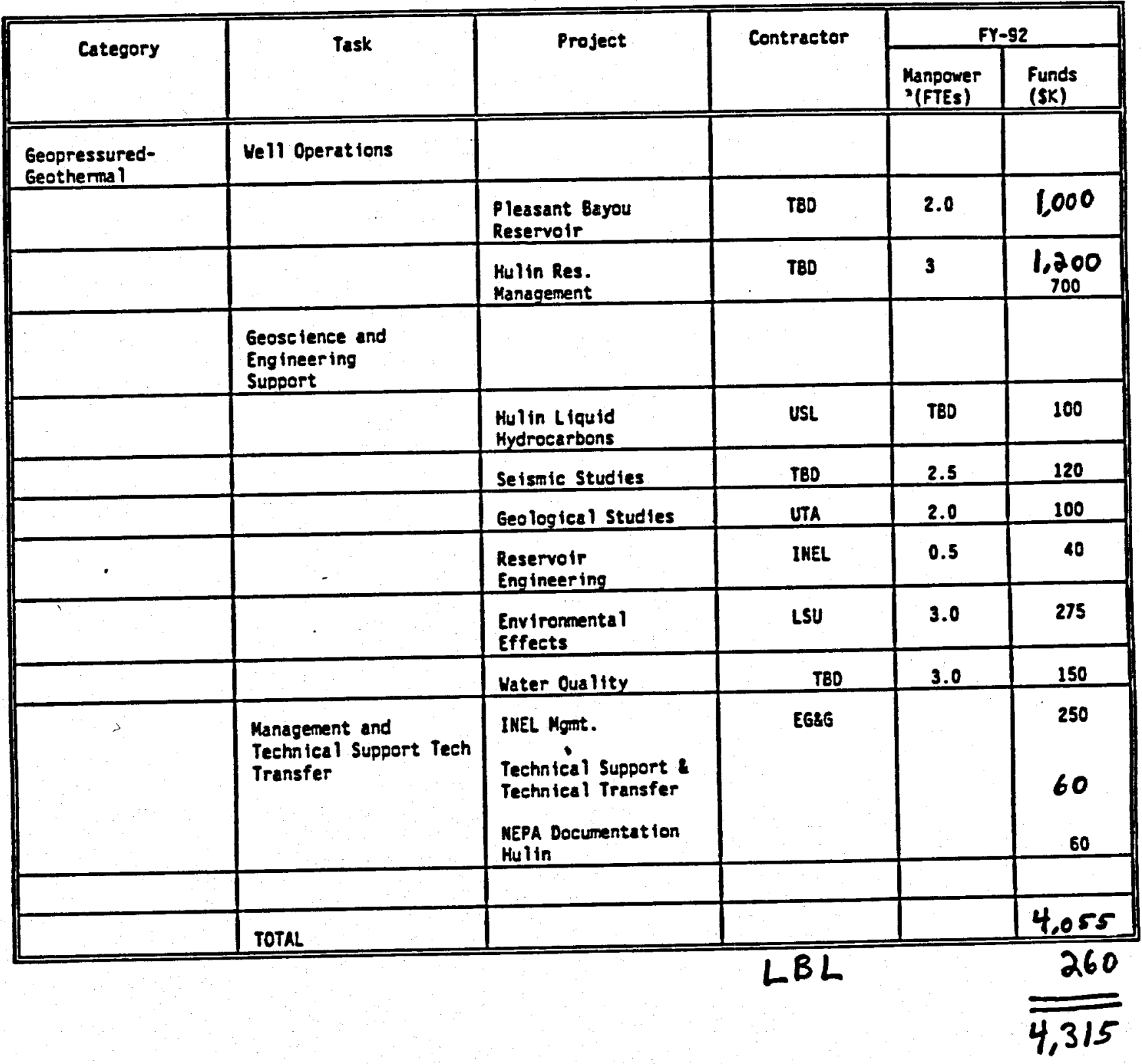

